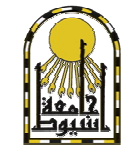

AUCES

\title{
ESTIMATING THE LOSSES OF HONEY BEE COLONIES AND THEIR POTENTIAL CAUSES WITHIN THE BEEKEEPERS AT ASSIUT GOVERNORATE (UPPER EGYPT), DURING THREE YEARS SURVEY BY USING QUESTIONNAIRE METHOD.
}

\author{
A.M. MOUSTAFA \\ Beekeeping Research Department, Plant Protection Research Institute (PPRI), \\ Agricultural Research Center, Dokki, Giza, Egypt
}

\begin{abstract}
:
This study records the data of three years, 2009/2010, 2010/2011 \& 2011/2012 survey of losses in managed honey bee colonies in Assiut governorate. The survey of colony losses and potential causes was obtained via questionnaire method. The surveyed beekeepers had loss a total of 4639 colonies between September and March. Colony loss percentages were 15.78 in 2009/2010; 28.11 in 2010/2011 and in 2011/2012 15.6. Survey information indicated that colony losses range widely depending on the operation size of the beekeepers. Commercial beekeepers (those operating more than $>200$ colonies) lost the lower number of colonies as compared to hobbyist, intermediate and semi-commercial beekeepers. Oriental hornets, poor quality queens, pesticides and CCD-like symptoms were the leading self-identified reasons of losses as reported by most beekeepers. Finally, it must circulate such as this questionnaire over all Egypt to understand the extent of the problem and try to find out the resolve.
\end{abstract}

Key words : Honey bee, Apis mellifera, colony loss, mortality, oriental hornets, poor quality queens, Upper Egypt, questionnaire.

\section{INTRODUCTION:}

Assiut is considered the oldest city in Egypt and it's the capital of Upper
Egypt and lies about $375 \mathrm{Km}$ south of

Cairo. Governorate consists of 11 
districts and 234 villages and 911

Manors. The common bee lines are hyrpried of Apis mellifera carnica and Apis m. ligustica, in addition to the local native bees of Apis m. lamarkii .

The management of honey bees is deeply considered in Assiut society; apiculture provides full or additional family income. There is a considerable market for bee products that are used as food and as additives for pharmaceutical and medical products. More importantly from a strictly economic perspective, honey bees are key pollinators for many agricultural crops. Indeed, honey bees are the most economically valued pollinators and it is estimated that $35 \%$ of human food consumption depends directly or indirectly on insect mediated pollination (Delaplane and Mayer, 2000).

Beekeepers in Assiut governorate have recently been confronted with unusually high losses of colonies. Wintering mortalities are well known to beekeepers, twenty years ago; it was acceptable to have 5 to $10 \%$ winter colony losses. Today, the losses are often up to $20 \%$ or more in many areas. The other expected losses can be expectable. There have been unexpected and alarming colony losses in different regions of the world in the past few years (Oldroyd, 2007; EFSA, 2008 and vanEngelsdorp et al., 2008).

Elevated colony losses have recently been reported from Europe (Crailsheim et al., 2009), USA (vanEngelsdorp et al., 2009; 2010), Middle East (Haddad et al., 2009; Soroker et al., 2009 Abdel-Rahman and Moustafa, 2012), and Japan (Guttierrez, 2009) .

Many well intentioned suggestions as to the possible causes of colony losses including such improbable ideas as mobile telephones, genetically modified crops and nanotechnology, have perhaps overshadowed the more much explanations such as pests and diseases, pesticides, loss of forage and beekeeping practices. Lack of hard field data on losses, limits a better understanding of the causative factors (Neumann, 2008).

The aim of the present study was to investigate the extent of colony losses problem and point out potential causes. 


\section{MATERIALS AND METHODS:}

This study was carried out in Assiut governorate, Upper Egypt. The map of Assiut governorate Fig. (1) Describes the eleven districts used for surveying the honey bee colony losses during three periods of September 2009 to March 2010, from September 2010 to March 2011, and from September 2011 to March 2012, respectively.

Questionnaire Method was used to survey the colony losses and potential causes by meetings; 104, 149 and 151 beekeepers at the respective years of study. Questionnaire form contained mainly the following questions :

1- In what district do you keep your hives?

2- How many colonies did you have alive in September?

3- How many colonies did you have alive until next March?

4- To what do you attribute the following cause(s) of death for the colonies that died?

Oriental hornets; Vespa orientals attack, American foul brood, Starvation, Poor queens, weather,
Varroa mite; Varroa destructor, Pesticides poisoning, phenomenon of Colony Collapse Disorder (CCD) - like symptoms, others.

To compare possible differences in colony losses among different sizes of operation, they were arranged into four groups namely; hobbyist beekeepers ( $\leq \mathbf{5 0}$ colonies), intermediate beekeepers (51-100 colonies), semi-commercial beekeepers (101-200) and commercial beekeepers $(>\mathbf{2 0 0}$ colonies). The mean number of dead colonies per beekeeper was divided by the mean number of colonies alive before winter. The resulting fraction was multiplied by 100 to give a percentage. The mean colony loss rate was calculated for each district, for various group classifications and for each possible cause (out of total loss) .

The mean of individual operation losses was calculated to determine the average loss among subgroups. 


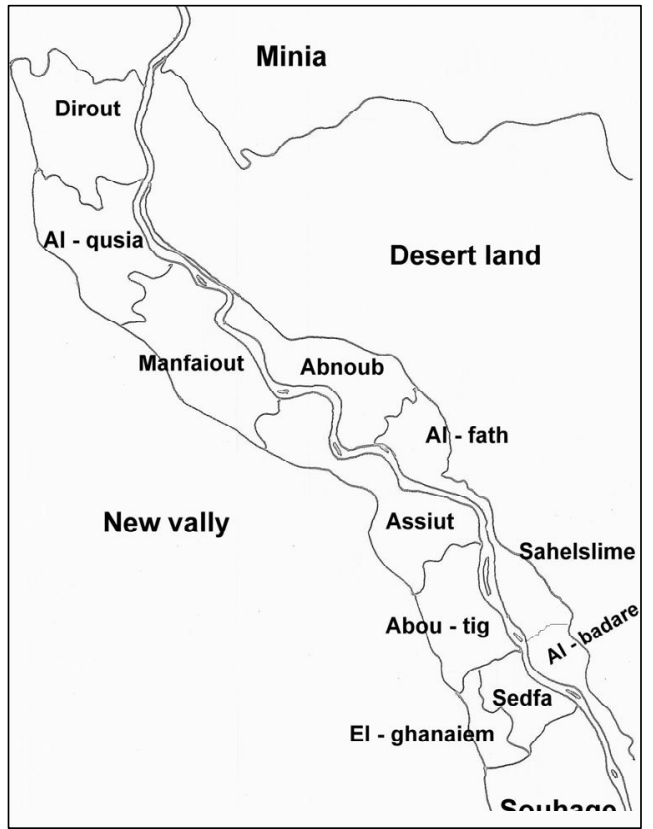

Fig. (1): Map of Assiut governorate depicted the districts used for survey.

Survey of responding beekeepers from eleven districts of Assiut governorate reported the honey bee colony losses on 2009/2010, 2010/2011 and 2011/2012 respectively. These districts namely: Dirout, Al - qusia, Manfalout, Assiut, Abnoub, Al - fath, Al - badarie, Sahelselime, Abou - tig, Sedfa and EI - ghanaiem.

\section{Statistical analyses:}

Percentages of colony losses were transformed using arcsine method, then, analysis of variance (ANOVA) was carried out using MSTAT-C software program (MSTAT-C, Michigan State University Version 2.10) and least significant difference (LSD) values were calculated when F-value were significant for times of introduction effects according to the method of Waller and Duncan (Waller and Duncan, 1969).

Results Losses in reference to the year:

One hundred and thirty eight beekeepers were responded to the Questionnaire survey during three years, 2009/2010, 2010/2011 \& 2011/2012. These beekeepers managed a total of 21891 colonies in September. The surveyed beekeepers had loss a total of 4639 colonies between September and March each year. Colony losses were $15.78 \%$ in $2009 / 2010 ; 28.11 \%$ in $2010 / 2011$ and in $2011 / 201215.6 \%$, respectively 
(Fig.1). Colony losses in 2010-2011were the highest in comparison with those of, 2009/2010 and 2011/2012 years.

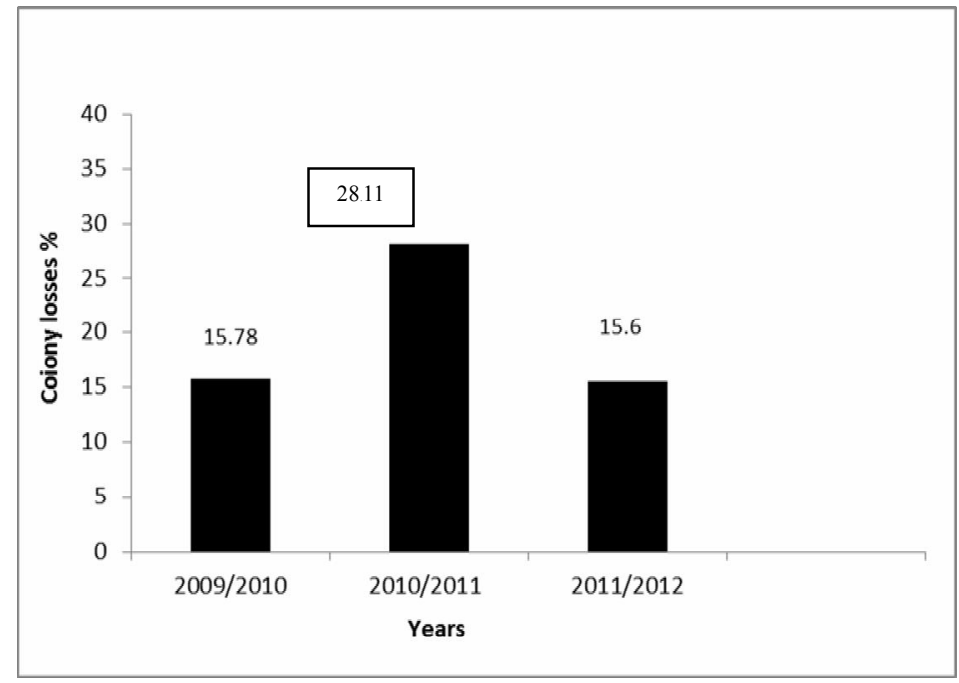

Fig. (1): Average colony losses among the respondents during the Years of, 2009/2010, $2010 / 2011 \& 2011 / 2012$.

In 2009/2010 season, the beekeeper were arranged in four groups, those who have less or equal to50 colonies constituted $32.03 \%$ out of the total respondents. The percentages of $35.92,23.30$ and 8.7 were to whom operate 50 to 100,100 to 200 and more than 200 colonies, respectively. In the second year of study, $22.5 \%$ of respondents own less-than or equal to 50 colonies. $30.62 \%$ of respondents operate 51 to 100 colonies and $19.37 \%$ of respondents operate 100 to 200 colonies. While, $2.7 \%$ of respondents were own more than 200 colonies. During 2011/2012, 32.33\% of the respondents whom own less-than or equal to 50 colonies, which constituted $33.83 \%$ of the total with those operate 51 to 100 colonies and $6.7 \%$ of respondents operate 100 to 200 colonies. While, $2.7 \%$ of respondents were own more than 200 colonies (Fig. 2, A). 

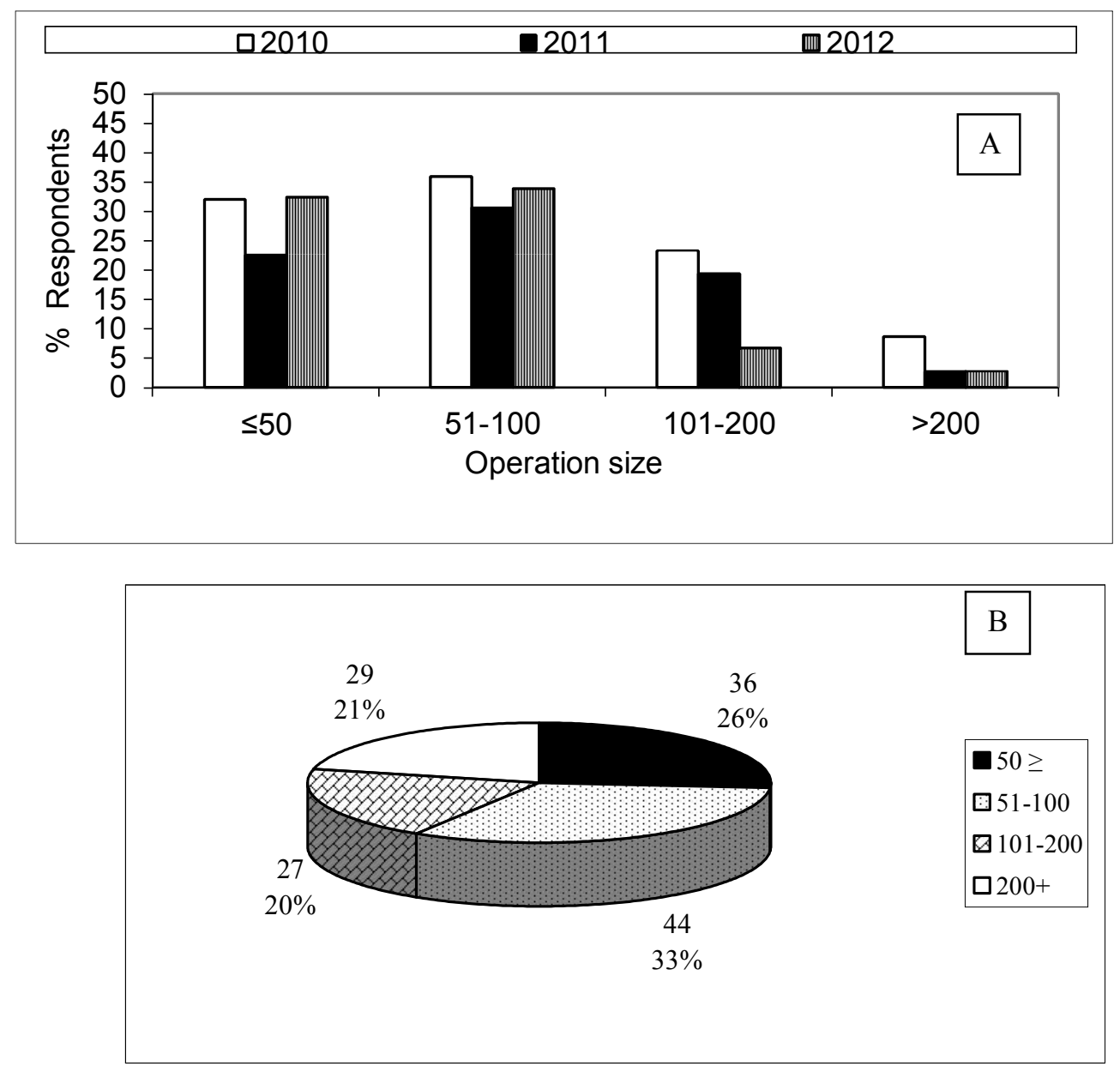

Fig. (2): Distribution of beekeeping operation size among respondents to the survey. A) Percentages of years, 2009/2010, $2010 / 2011 \& 2011 / 2012$.

B) General total and mean.

In general, the beekeepers who contributed the data can be arranged as $27 \%$ of respondents, hobbyist beekeepers, operate $\leq 50$ colonies. $32 \%$ of respondents, intermediate beekeepers, operate $51-100$ colonies, $20 \%$ of respondents, semi-commercial beekeepers operate 101-200 colonies. In addition, only nearly $21 \%$ of respondents, commercial beekeepers, operate $>200$ colonies (Fig. 2, B). 
Losses in reference to studied district:

The numbers and percentages of colony losses by over the district are summarized in Table 1. It may be noted that there wasn't considerable variation in the percentage average of colony losses in both 2009/2010; 2011/2012 and 2010/2011, and general mean. The data was showed lost $15.78 \%$ and15.60 during 2009 / 2010 and 2011/2012. While, the highest of loss $28.11 \%$ was obtained on 2010/2011.

Table (1): Total numbers and percentages of colony losses in districts of Assiut

Governorate during three years, 2009/2010, 2010/2011 \& 2011/2012.

\begin{tabular}{|c|c|c|c|c|c|c|c|c|c|}
\hline \multirow[b]{3}{*}{ Districts } & \multicolumn{9}{|c|}{ Colony losses (No. \& \% ) } \\
\hline & \multicolumn{3}{|c|}{$2009 / 2010$} & \multicolumn{3}{|c|}{$2010 / 2011$} & \multicolumn{3}{|c|}{$2011 / 2012$} \\
\hline & $\begin{array}{l}\text { No. of colo- } \\
\text { nies at Sep- } \\
\text { tember } 2009\end{array}$ & $\begin{array}{l}\text { No. } \\
\text { March } \\
2010\end{array}$ & $\begin{array}{l}\% \\
\text { losses }\end{array}$ & $\begin{array}{l}\text { No. of colo- } \\
\text { nies at Sep- } \\
\text { tember } \\
2010\end{array}$ & $\begin{array}{l}\text { No. } \\
\text { March } \\
2011\end{array}$ & $\begin{array}{l}\% \\
\text { losses }\end{array}$ & $\begin{array}{l}\text { No. of colo- } \\
\text { nies at Sep- } \\
\text { tember } 2011\end{array}$ & $\begin{array}{l}\text { No. March } \\
2012\end{array}$ & $\begin{array}{l}\% \\
\text { losses }\end{array}$ \\
\hline Dirout & 678 & 121 & 17.84 & 4030 & 913 & 22.65 & 1336 & 200 & 14.97 \\
\hline Al - qusia & 488 & 105 & 21.51 & 1730 & 454 & 26.24 & 236 & 18 & 7.92 \\
\hline Manfalout & 1175 & 210 & 17.87 & 5825 & 1572 & 26.98 & 9880 & 1568 & 15.87 \\
\hline Assiut & 3015 & 422 & 13.99 & 5251 & 1410 & 26.85 & 5608 & 849 & 15.13 \\
\hline Abnoub & 700 & 191 & 27.28 & 1653 & 321 & 19.41 & 44003 & 366 & 9.14 \\
\hline Al - fath & 1535 & 250 & 16.28 & 2444 & 756 & 3093 & 1740 & 438 & 25.17 \\
\hline Sahelslime & 1231 & 202 & 16.40 & 1131 & 436 & 38.54 & 1962 & 358 & 18.24 \\
\hline Al - badare & 1184 & 157 & 13.26 & 300 & 121 & 40.33 & 353 & 51 & 14.44 \\
\hline Apo - tig & 1140 & 101 & 8.85 & 2615 & 806 & 30.82 & 1792 & 274 & 15.29 \\
\hline Sedfa & 628 & 101 & 16.08 & ב638 & 408 & 63.94 & 900 & 213 & 23.66 \\
\hline EI - ghanaiem & 130 & 19 & 14.61 & 116 & 39 & 33.62 & 122 & 24 & 19.67 \\
\hline $\begin{array}{l}\text { General Total } \\
\& \text { Mean }\end{array}$ & 11904 & 1879 & 15.78 & 25733 & 7236 & 28.11 & 4359 & 27932 & 15.60 \\
\hline
\end{tabular}




\section{Losses in reference to the operation size:}

It was found that the commercial operations that managed colonies of 101 to 200 and $>200$ tended to have lower average losses, which were significantly different from the operations that managed the small colonies of $\leq 50$ and 51 to100 (Table 2).

Table (2): Average loss experienced by all responding beekeepers grouped by operation size during three years, 2009/2010, $2010 / 2011 \& 2011 / 2012$.

\begin{tabular}{|c|c|c|c|}
\hline Operation size & Number of respondents & $\begin{array}{c}\text { Number of colonies } \\
\text { managed in Septem- } \\
\text { ber }\end{array}$ & $\begin{array}{c}\text { Average loss \% } \\
\pm \text { S.E. }\end{array}$ \\
\hline$\leq 0$. & 36 & 1303 & $\begin{array}{c}31.38 \text { a } \\
\pm 4.832\end{array}$ \\
\hline 51 to100 & 44 & 3510 & $\begin{array}{c}29.55 \text { a } \\
\pm 5.342\end{array}$ \\
\hline 101 to 200 & 27 & 3543 & $\begin{array}{c}20.8 \quad b \\
\pm 2.73\end{array}$ \\
\hline$>200$ & 29 & 13535 & $\begin{array}{c}18.15 \mathrm{~b} \\
\pm 5.48\end{array}$ \\
\hline
\end{tabular}

Different letters in differen.t rows indicate significantly different.

The numbers and percentages of colony losses due to the operation size are recorded in Table $3 \&$ Fig. 3 . There was considerable variation in the percentage of loss suffered accompanied by operation size. The high percentages loss of 4113 and 38.75 were noticed for the size group less-than or equal to 50 and group 51-100 colonies in 2010/2011. While, the low percentage of los; 26.57 and 25.09 were showed for the size operation $101-200$ and $>200$ colonies in the same year. 
Table (3): Total and percentages of colony losses experienced by all responding beekeepers in Assiut Governorates during three years, 2009/2010, 2010/2011 \& 2011/2012.

\begin{tabular}{|c|c|c|c|c|c|c|}
\hline \multirow{2}{*}{ years } & \multirow{2}{*}{$\begin{array}{l}\text { No. of respondents and Col- } \\
\text { ony losses } \\
\text { (No. \& \% ) }\end{array}$} & \multicolumn{4}{|c|}{ Colony losses } & \multirow[b]{2}{*}{$\begin{array}{l}\text { General total } \\
\text { and mean }\end{array}$} \\
\hline & & $\leq \mathbf{5 0}$ & $51-100$ & $101-200$ & $>\mathbf{2 0 0}$ & \\
\hline \multirow{5}{*}{ 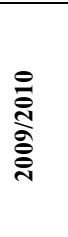 } & respondents & $2 \pi$ & 37 & 24 & 9 & 103 \\
\hline & September, 2009 & 1206 & 3114 & 3698 & 3890 & 11908 \\
\hline & March, 2010 & 346 & 636 & 591 & 240 & 1813 \\
\hline & \% of losses & 28.68 & 20.42 & 15.98 & 6.16 & 17.81 \\
\hline & Rank & 1 & 2 & 3 & 4 & \\
\hline \multirow{5}{*}{ 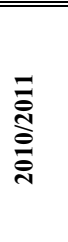 } & respondents & 36 & 49 & 31 & 44 & 160 \\
\hline & September, 2010 & 1252 & 3891 & 3150 & 17440 & 25733 \\
\hline & March ,2011 & 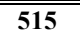 & 1508 & 837 & 43376 & $7 \overline{7236}$ \\
\hline & \% of losses & 41.13 & (38.75 & 2 & 25.09 & 32.885 \\
\hline & Rank & 1 & 2 & 3 & 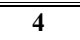 & \\
\hline \multirow{5}{*}{ 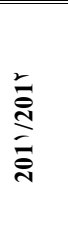 } & No. of respondents & 43 & 45 & 9 & 36 & 133 \\
\hline & September, 2010 & 1452 & 3526 & 3777 & 19277 & 28032 \\
\hline & March, 2011 & 366 & 968 & 702 & 2753 & 4789 \\
\hline & \% losses & 25.20 & 27.45 & (18.58 & 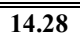 & 21.3775 \\
\hline & Rank & 1 & $\overline{2}$ & $\bar{c}$ & $\overline{74}$ & \\
\hline
\end{tabular}

The same trend was reported in $2009 / 2010$, where the high percentage of loss; 28.68 and 20.42 were recorded for the operation size $\leq 50$ and 51-100 colonies. Also, the low percentage loss of 15.98 and 6.16 were noticed for the size operation101-200 and $>200$ colonies. Also the same trend was found in 2011/2012 where the high percentage loss of $\mathbf{2 5 . 2 0}$ and $\mathbf{2 7 . 4 5}$ were recorded for the operation size $\leq \mathbf{5 0 a n d} 51$ 100 colonies. Also, the low percentage loss of 18.58 and 14.28 were noticed for the size operation 101-200 and $>200$ colonies. 


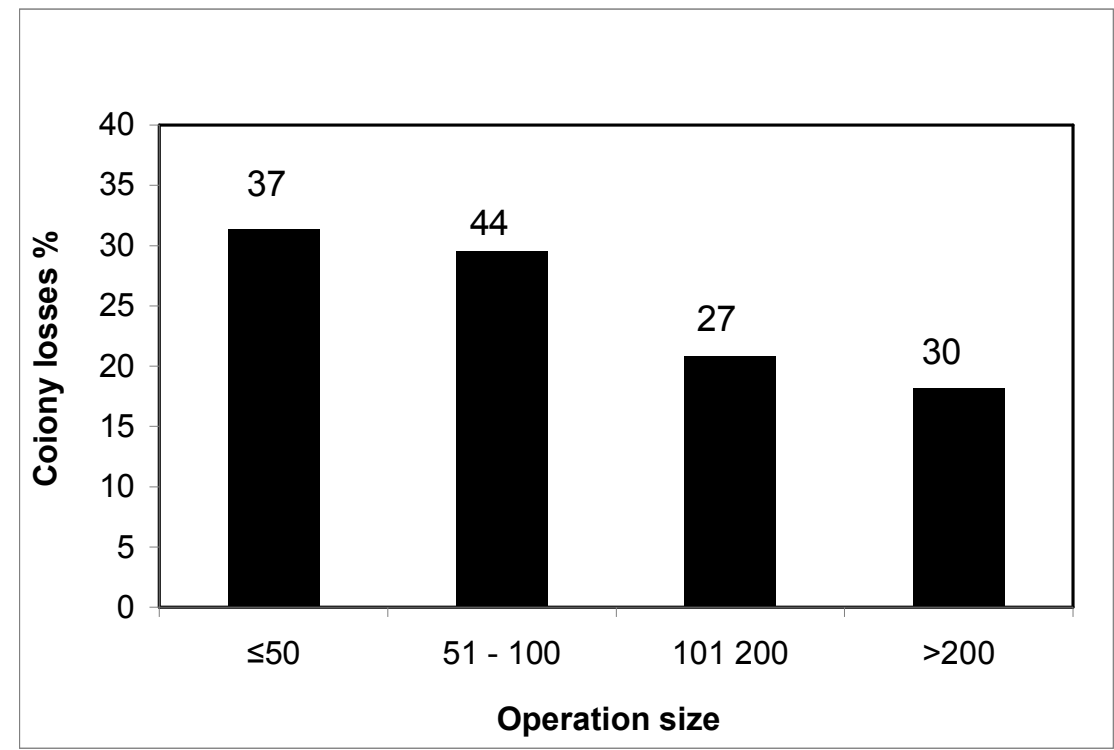

Fig. (3): Average loss levels among the responding beekeepers divided according to the operation size during three years 2009/201, 2010/2011 \& 2011/2012.

Generally, the level of colony losses varied widely among the different size of operations. The depicted, smaller operations are more likely to have got more losses than the largest operations. The average of loss percentages of 31.38, 29.55, 20.8 and 18.15 were recorded for the hobbyist, intermediate, semi-commercial and commercial beekeepers, respectively (Fig.3).

Factors that explaining losses of colony inside the different groups of operation size illustrated in Table 4 and Fig. 4. The causes of losses varied widely among the size of operations. The smaller operations are more likely to have suffered from oriental hornet more severe losses than largest operations. While the largest operations are more likely to suffer from Poor queens more than smaller operations. 
Table (4): Factors affecting the colony losses during three years, 2009/2010, $2010 / 2011 \& 2011 / 2012$.

\begin{tabular}{|c|c|c|c|c|c|c|c|c|c|}
\hline \multirow{2}{*}{$\begin{array}{c}\text { Opera- } \\
\text { tion } \\
\text { size }\end{array}$} & \multirow[b]{2}{*}{$\begin{array}{c}\text { Mean } \\
\& \%\end{array}$} & \multicolumn{8}{|c|}{ Factors } \\
\hline & & $\begin{array}{c}\text { Oriental } \\
\text { hornet }\end{array}$ & $\begin{array}{c}\text { Varroa } \\
\text { mite }\end{array}$ & AFB & $\begin{array}{l}\text { CCD-like } \\
\text { symptoms }\end{array}$ & Pesticides & Weather & $\begin{array}{c}\text { Poor } \\
\text { queens }\end{array}$ & $\begin{array}{c}\text { Starva- } \\
\text { tion }\end{array}$ \\
\hline \multirow{2}{*}{$\leq \mathbf{5 0}$} & Mean & 175.33 & 25 & 24.66 & 48 & 18 & 21.66 & 92 & 4.33 \\
\hline & $\%$ & 42.8701 & 6.112 & 6.029 & 11.736 & 4.401 & 5.296 & 22.495 & 1.058 \\
\hline \multirow[b]{2}{*}{ 51- 100} & Mean & 252.66 & 94.33 & 131.66 & 147.66 & 84 & 36.33 & 235.33 & 55.33 \\
\hline & $\%$ & 24,357 & 9.093 & 12.693 & 14.235 & 8.097 & 3.502 & 22.686 & "5.334 \\
\hline \multirow{2}{*}{$101-200$} & Mean & 195.66 & 42.66 & 100.66 & 33.66 & 39.33 & 60.66 & 182 & 82.33 \\
\hline & $\%$ & 26.549 & 5.788 & 13.659 & 4.567 & 5.3367 & 8.231 & 24.696 & 11.171 \\
\hline \multirow{2}{*}{$>200$} & Mean & 443.33 & 187 & 230.66 & 142 & 311.33 & 252.33 & 720.66 & 169 \\
\hline & $\%$ & 18.048 & 7.613 & 9.390 & 5.781 & 12.674 & 10.272 & 29.339 & 6.880 \\
\hline
\end{tabular}

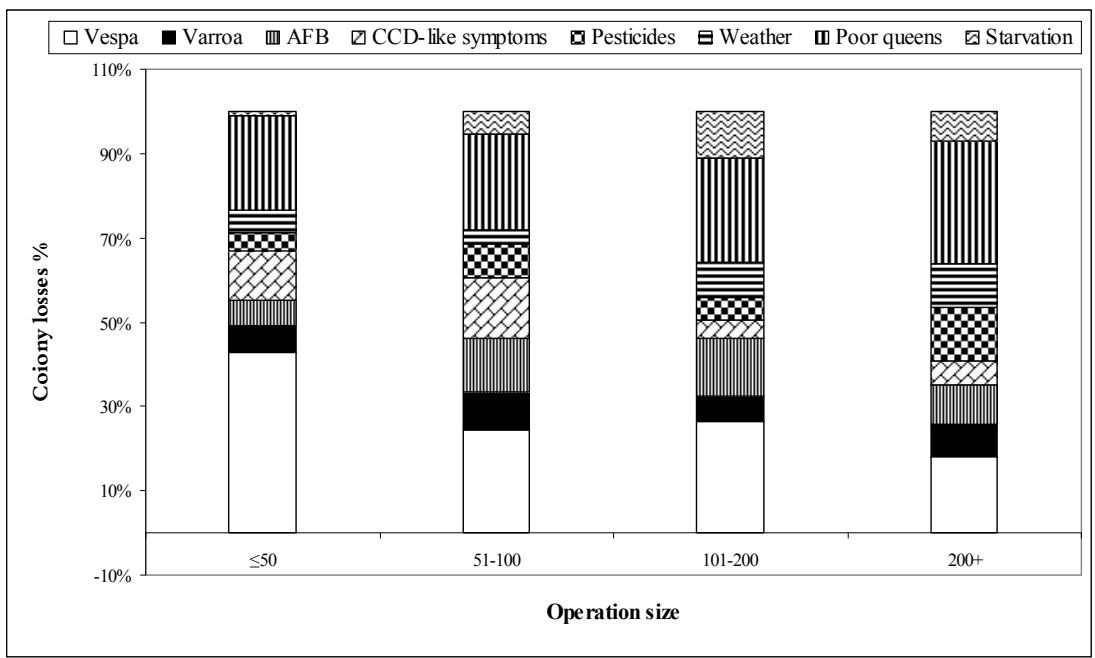

Fig. (4): Factors affecting the colony losses during three years, 2009/2010, $2010 / 2011 \&$ 2011/2012. 
The Perceived reason(s) of colony losses:

When the respondents were asked to identify the reasons they thought to responsible for colony losses, they listed eight different potential causes of colony mortality most frequently (Table5). The importance of these causes listed by beekeepers were clearly differed among the years of questionnaires 2009/201，2010/2011 and 2011/2012. For instance, oriental hornet, caused $30.81,25.13 \%$ and 16.86 of colony losses during three years, 2009/2010, $2010 / 2011$ and 2011/2012, respectively. Another example,
Pesti pesticides caused $5 \%, 4.25 \%$ and $\mathbf{2 0 . 0 5 \%}$ of colony losses during three years, 2009/2010, $2010 / 2011$ and 2011/2012, respectively. The loss caused by AFB had decreased from $21.12 \%$ in $2009 / 2010$ to $6.75 \%$ in 2010/2011 and $12.18 \%$ in 2011/2012. This due to the fact that AFB disease is being kept reasonably under control. While, the important of poor queens nearly wasn't differentiating, while this factor responsible for $\mathbf{2 3 . 3 6}$, $32.93 \%$ and $16.54 \%$ of colony losses during three years 2009/2010, 2010/2011 and 2011/2012, respectively.

Table (5): The commonly causes perceived of colony losses recorded on March of three years, 2009/2010, 2010/2011 \& 2011/2012 in Assiut Governorate.

\begin{tabular}{|c|c|c|c|c|c|c|c|c|c|c|}
\hline \multirow[b]{2}{*}{ Years } & \multirow{2}{*}{$\begin{array}{c}\text { Colony losses } \\
(\%)\end{array}$} & \multicolumn{8}{|c|}{ causes of colony losses } & \multirow[b]{2}{*}{ Total } \\
\hline & & \begin{tabular}{|l} 
Oriental \\
hornet
\end{tabular} & $\begin{array}{l}\text { Varroa } \\
\text { mite }\end{array}$ & AFB & $\begin{array}{l}\text { CCD- like } \\
\text { symptoms }\end{array}$ & Pesticides & Weather & $\begin{array}{l}\text { Poor } \\
\text { queens }\end{array}$ & Starvation & \\
\hline \multirow[b]{2}{*}{$2009 / 2010$} & \% of losses & 30.81 & 8.46 & 21.12 & 4.52 & 6.433 & 2.98 & 23.36 & 3.35 & 100 \\
\hline & Rank & 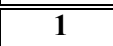 & 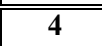 & $\overline{73}$ & $\bar{~} 6$ & $\overline{5}$ & $\overline{88}$ & 2 & $\overline{77}$ & \\
\hline \multirow[b]{2}{*}{$2010 / 2011$} & \% of losses & 25.13 & 8.00 & 6.75 & 9.09 & 4.25 & 7.42 & 32.93 & (6.39 & 100 \\
\hline & Rank & 2 & 4 & 6 & 3 & 8 & 5 & 1 & 7 & \\
\hline \multirow[b]{2}{*}{$2011 / 2012$} & \%\% of losses & 16.86 & 6.56 & 12.18 & 7.79 & 20.05 & 12.27 & 16.54 & 6.58 & 100 \\
\hline & Rank & 2 & 8 & 5 & 6 & 1 & 4 & 3 & 7 & \\
\hline
\end{tabular}




\section{Discussion:}

Information quantifying on honey bee colony losses has been collected for Assiut governorate. This is an important data set that wills all subsequent fluctuations to be properly monitored. Colony losses in 2010-2011 were the highest in comparison to both $2009 / 2010$ and 2011/2012 years. This is agreement with Abdel-rahman and Moustafa (2012), who recorded the colony losses in 2010/2011 the highest in fall and winter in Upper Egypt (Qena \& Luxor Governorates, where beekeeper lost about $30.73 \%$ of colonies. The distribution of colony losses during three years, 2009/2010, 2010/2011 \& 2011/2012 showed a different variation among Assiut districts (Table 1).

The highest of figures beekeepers lost constituted about $31.38 \%$ of their colonies for the group who owned less-than or equal to 50 colonies (Fig. 3), which is in agreement of Abdel rahman and Moustafa, (2012). This finding suggests that the apiary management plays an important role. This group is usually kept to make some extra money and the main source of income lies out-side beekeeping. Therefore, beekeepers often cannot devote sufficient time to dealing properly with their problems or to prevent or control the bee disease. Moreover due to they have not enough experiences. The professional management might have played a significant role in prevention of losses. Also, higher losses in small operations were found in Poland (Topolska et al., 2008) and in Israel (Soroker et al., 2011) but not in US (vanEn-gelsdorp et al., 2008).

There are undoubtedly various causes for colony losses. Responding beekeepers most frequently selfidentified causes such as, oriental hornet; weather; AFB and poor quality queens, as the leading causes of mortality in their operations (Table5). Survey information indicates that about $24 \%$ of all the colonies lost during 2009/2010 and 2010/2011, died by oriental hornet (Hussein and Shoreit, 2000) recorded the oriental 
hornet attacking honey bee colonies and is a major predator of honey bees and destroy entire apiaries in Upper Egypt.

The primary perceived problem for beekeepers was poor queens $(23 \%$ out of losses). In USA, poor queen and starvation played a key role in colony losses from fall 2007 to spring 2008 (vanEngelsdorp et al., 2008). A queen's quality is not only a function of her own reproductive potential but also how well she is mated. Camazine et al. (1998) estimated the number of sperm in the spermathecae of 325 queens from 13 different commercial queen breeders. They found that $19 \%$ of the queens were "poorly mated" (i.e., they carried fewer than 3 million sperm), as defined by Woyke (1962).

The number of stored sperm, however, is not the only measure of a queen's mating success. Queens are highly polyandrous, mating with an average of 12 drones on their mating flight(s) early in life (Tarpy and Nielsen, 2002). It has been shown that polyandry, and the resultant intracolony genetic diversity of the worker force, confers numerous benefits to a colony (Palmer and Oldroyd, 2000). First, genetic diversity may increase the behavioral diversity of the worker force (Fuchs and Schade, 1994,Moritz and Fuchs, 1998, Mattila and Seeley, 2007), such as enabling colonies to exploit different foraging environments more efficiently (Lobo and Kerr, 1993 and Mattila et al., 2008) Second, genetic diversity may reduce the impacts of diploid male production as a consequence of the single-locus sex determination system (Ratnieks, 1990; Tarpy and Page, 2002). Third, genetic diversity may reduce the prevalence of parasites and pathogens among colony members (Hamilton, 1987, Sherman et al., 1988, Palmer and Oldroyd, 2003, Tarpy, 2003, Cremer et al., 2007, Seeley and Tarpy, 2007 and WilsonRich et al., 2009). Thus determining the number of mates by a queen, and not just the number of sperm, is one final measure of a queen's reproductive quality. Determining the factors that result in low-quality queens is therefore of fundamental importance for improving colony productivity and fitness. 
This survey information indicates that, about $7 \%$ of all the colonies lost losses during three years, 2009/2010, 2010/2011 \& 2011/2012 in Assiut Governorate, died by CCD-like symptoms. As a result of climatic differentiation, there are differences between the countries and the regions for reasons lead to colony losses. Malnutrition is a stress factor to bees; a weak immune system can affect a bee's ability to fight pests and diseases as well as immunosuppressant caused by pathogen or parasite attack (Glinski \& Kostro, 2007). In Poland, and Canada, Varroa destructor (with associated virus infections) and Nosema spp. Played the same role in colony losses during the winter (Pernal, 2008). A mixture of original research articles; addressed the possible causes of honey bee colony losses: virus (Berthoud et al., 2010, Carreck et al., 2010 a, b and Martin et al., 2010), Nosema ceranae (Paxton, 2010 and Santrac et al., 2010); Varroa destructor (Carreck et al., 2010 b, Dahle, 2010 and Martin et al., 2010), Pesticides (Chauzat et al., 2010 and Medrycki et al., 2010), the effects of acaricides (Harz et al., 2010), the loss of genetic diversity (Meixner et al., 2010) and loss of the habitats (Potts et al., 2010). Scientists are investigating the lack of genetic diversity and lineage of bees, both related to queen quality, as possible causes of CCD. This lack of genetic biodiversity can make bees increasingly susceptible to any pest or disease that invades the system. The importance of genetic diversity has been noted at the individual the colony, the population and subspecies level in honey bees. There are examples of reduced fitness at the individual and colony level, due to reduce genetic.

Increased rates of colony losses in Upper Egypt are probably the result of regional differences in weather patterns that affected forage availability of bees, starvation, Vespa, foulbrood and other diseases, in addition to poor quality queens and pesticides. These stresses interacting in combination with each other affected colony survival are believed to be the most important factors related to colony losses. 


\section{REFERENCE:}

Abdel Rahman M.F. and A.M. Mustafa (2012). An estimate of honey bee colony losses and their perceived reasons during two years case study in Qena and Luxor Governorates, Upper Egypt. Assiut J. of Agric. Sci., 43:164-178.

Berthoud, H.; A. Imdorf; M. Haueter; S. Radloff and P. Neumann (2010). Virus infections and winter losses of honey bee colonies (Apis mellifera). J. apic. Res., 49(1): 60-65.

Camazine S.; I.Çakmak; K. Cramp; J.Finley；J. Fisher;M. Frazier; A.Rozo (1998). How healthy are commercially-produced US honey bee queens? Am. Bee J. 138: 677680.

Carreck, N.L.; B.V. Ball and S.J. Martin (2010a). The epidemiology of cloudy wing virus infections in honey bee colonies in the UK. J. apic. Res. 49(1): 66-71.
Carreck, N.L.; B.V. Ball and S.J. Martin (2010b). Honey bee colony collapse and changes in viral prevalence associated with Varroa destructor. J. apic. Res., 49(1): 93-94.

Chauzat, M.P.; A.C. Martel; P. Blanchard; M.C. Clément, F. Schurr; C. Lair; M. Ribière; K. Wallner; P. Rosenkranaz and J. P. Fau-con (2010). A case report of a honey bee colony poisoning incident in France. J. apic. Res., 49(1): 113-115.

Crailsheim, k; R. Brodschneider and P. Neumann (2009). The coloss puzzle: filling in the gaps. In: Proceedings of the 4th COLOSS Conference, 3-4 March 2009. Zagreb, Croatia, p. 46-47.

Cremer S.; S.A.O. Armitage and P. Schmid-Hempel (2007). Social immunity. Curr. Biol. 17: 693 702. 
Dahle, B. ( 2010). The role of Varroa destructor for honey bee colony losses in Norway. J. apic. Res., 49(1):124-125.

Delaplane K.S.and D.F.Mayer (2000). Crop pollination by bees, $\mathbf{C A B}$, New York.

EFSA (European Food Safety Agency) (2008). A report by the Assessment Methodology Unit in response to Agence de Securite Sanitaire des Aliments (AFSSA): Bee mortality and bee surveillance in Europe, EFSA. J. 154128.

Fuchs S. and V. Schade (1994). Lower performance in honey bee colonies of uniform paternity. Apidologie, 25: 155-16.

Glinski, Z. and K. Kostro (2007). Colony Collapse Disorder - a new threatening disease of honey bees. Zycie Weterynaryjne, 82 (8): 651-653.

Gutierrez, D (2009). Honey bee collapse strikes Japan, up to fifty percent of honey bees gone... Natural News, 28 April2009. www.naturalnews.com/026151_J apan_honey bees_honey.htm.

Haddad, N; A. Bataenth; I.Albaba; D.Obeid and S. Abdulrahman (2009). Status of colony losses in the Middle East. In: Proceedings of the 41st Apimondia Congress, Mointpellier, France. p.36.

Hamilton W.D. (1987). Kinship, recognition, disease, and intelligence: constraints of social evolution, in: Kikkawa J. (Ed.), Animal Societies: Theory and Facts, Japanese Scientific Society Press, Tokyo, pp. 81-102.

Harz, M.; F. Müller and E. Rademacher (2010). Organic acids: Acute toxicity on Apis mellifera recovery in the haemolymph. J. Apic. Res., 49(1):95-96.

Hussein, M.H. and M.N. Shoreit, (2000). Abundance of the oriental hornet (Vespa orientalis) and a large scale extension service for its control in Egypt. 2nd Scien- 
tific Conference of Agricultural

Sciences, Assiut, Oct., 2: 667-672.

Lobo J.A. and W.E. Kerr (1993).

Estimation of the number of matings in Apis mellifera: Extensions of the model and comparison of different estimates. Ethol. Ecol. Evol. 5:337-345.

Lodesani M., D. Balduzzi and A. Galli (2004) .A study on spermatozoa viability over time in honey bee (Apis mellifera ligustica) queen spermathecae. J. Apic. Res. 43, 27-28.

Martin, S.J.; B.V. Ball and N.L. Carreck (2010). Prevalence and persistence of deformed wing virus (DWV) in untreated or acaricide treated Varroa destructor infested honey bee (Apis mellifera) colonies. J. Apic. Res., 49(1): 72-79.

Mattila H.R.; K.M. Burke and T.D. Seeley (2008). Genetic diversity within honey bee colonies increases signal production by waggle-dancing foragers. Proc. R. Soc. Lond. B 275:809-816.
Mattila H.R. and T.D. Seeley (2007). Genetic diversity in honey bee colonies enhances productivity and fitness. Science, 317:362-364.

Medrzycki, P.; F. Sgolastra; L. Bortolotti; G. Bogo; S. Tosi; E. Padovani; C. Porrini and A.G. Sabatini (2010). Influence of brood rearing temperature on honey bee development and susceptibility to poisoning by pesticides. J. Apic. Res., 49 (1): 52-59.

Meixner, M.D.; C. Costa; P. Kryger; F. Hatjina; M. Bouga; E. Ivanova and R. Büchler (2010). Conseving diversity and vitality for honey bee breeding. J. apic. Res., 49(1): 85-92.

Moritz R.F.A. and S. Fuchs (1998). Organization of honey bee colonies: characteristics and consequences of a superorganism concept. Apidologie, 29: 7-21.

Neumann, P. (2008). An introduction to honey bee colony losses. In Proceeding of the 3rd European Conference of Apidologie, Belfast, 2008. 
Oldroyd P.B. (2007). Unsolved mystery: what's killing American honey bees? PLoSBiol., doi: 10.1371/journal.pbio.0050168. g001

Palmer, K.A. and B.P. Oldroyd (2000). Evolution of multiple mating in the genus Apis. Apidologie, 31:235-248.

Palmer, K.A. and B.P. Oldroyd (2003). Evidence for intra-colonial genetic variance in resistance to American foulbrood of honey bees (Apis mellifera): further support for the parasite/pathogen hypothesis for the evolution of polyandry. Nat. Wiss., 90: 265-268.

Paxton, R.J. 2010. Does infection by Nosema ceranae cause "Colony Collapse Disorder" in honey bees (Apis mellifera)?. J. apic. Res., 49(1): 80-84.

Pernal, S.F. (2008). Canadian Association of Professional Apiculturist (CAPA) Statement on honey bees losses in Canada (Spring 2008), Final revision. http://www.capabees.com/main/fi les/pdf/conwintlossnewrev.pdf

Accessed 23 April 2012.

Potts, S.G.; S.P.M. Roberts; R. Dean; G. Marris; M.A. Brown; H.R. Jones; P. Neumann and J. Settele( 2010). Declines of managed honey bees and beekeepers in Europe. J. Apic. Res., 49(1): 1522.

Ratnieks F.L.W. (1990). The evolution of polyandry by queens in social Hymenoptera: the significance of the timing of removal of diploid males. Behav. Ecol. Sociobiol. 26, 343-348.

Santrac, V.; A. Granato and F. Mutinelli (2010). Detection of Nosema ceranae in Apis mellifera from Bosnia and Herzegovina. J. Apic. Res., 49(1): 100101.

Seeley T.D. and D.R. Tarpy (2007). Queen promiscuity lowers disease within honey bee colonies. Proc. R. Soc. Lond. B 274: 67-72. 
Sherman P.W., Seeley T.D. and H.K. Reeve (1988). Parasites, pathogens, and polyandry in social Hymenoptera. Am. Nat., 131: 602-610.

Soroker, V.; A. Hetzroni; B. Yakobson; D. David; A. David; H. Voet; Y. Slabezki; H. Efrat; S.Levski; Y. Kamer; E. Klinberg; N. Zioni; S. Inbar and N. Chejanovsky (2011). Evaluation of colony losses in Israel in relation to the incidence of pathogens and pests. Apidologie, 42(2):192199.

Soroker, V; A. Hetzroni; B. Yacobson; H. Voet; S. Slabezki; H. Efrat. and N. chejanovsky (2009). Colony losses in Israel: incidence of viral infection and beehive populations. In: Proceedings of the 41st Apimondia Congress, Mointpellier, France. p.38.

Tarpy D.R. (2003). Genetic diversity within honey bee colonies prevents severe infections and promotes colony growth, Proc. R. Soc. Lond., B 270: 99 - 103.
Tarpy D.R .and D.I. Nielsen. (2002). Sampling error, effective paternity, and estimating the genetic structure of honey bee colonies (Hymenoptera: Apidae). Ann. Entomol. Soc. Am., 95: 513-528.

Tarpy D.R. and R.E. Jr. Page (2002). Sex determination and the evolution of polyandry in honey bees (Apis mellifera). Behav. Ecol. Sociobiol., 52: 143-150.

Topolska, G.; A. Gajda and A. Hartwig (2008). Polish honey bee colony-loss during the winter of 2007-2008. J. apic. Sci., 52: 95104.

VanEngelsdorp D., J. Jr. Hayes; R.M Underwood and J.S. Pettis (2008). A survey of honey bee colony losses in the U.S. Fall 2007 to spring 2008. Plos One,3:e4071, doi:10.1371/ journal. Pone. 004071.

VanEngelsdorp, D.; J. Hayes; R.M. Underwood and J.S. Pettis (2010). A survey of honey bee colony losses in the United States, 
fall 2008 to spring 2009. J. apic. Res., 49(1): 7-14.

vanEngelsdorp, D.; J.D. Evans; C.

Saegerman; C. Mullin; E.

Haubruge; B.K. Nguyen; M.

Frazier; J. Frazier; D. Coxfoster;

Y. Chen; R.M. Underwood; D.R.

Tarapy and J.S. Pettis (2009).

Colony Collapse Disorder: A

descriptive study. Plos One, 4: e6481.

Waller, R.A. and D.P. Duncan (1969).

A bays rule for symmetric multiple comparison problem. Amer.

Stat. Assoc. J., 1485-1503.
Wilson-Rich N., Spivak M., Fefferman N.H. and P.T.Starks (2009). Genetic, individual, and group facilitation of disease resistance in insect societies, Annu. Rev. Entomol. 54: 405-423.

Woyke J. (1962). Natural and artificial insemination of queen honey bees. Bee World, 43: 21-25. 


\section{تقديو الهقد المادث في طوانف نمل المسل وأسبابه لامتمبة لدي همبي النمل

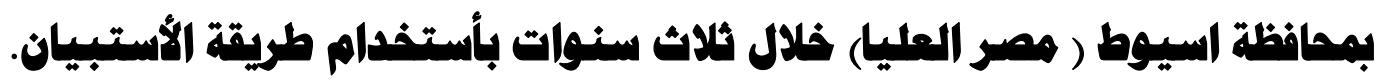

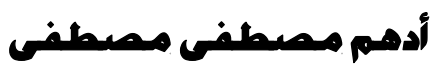

$$
\text { قسم بحوث النحل - معهز بحوث وقاية النباتات - مركز البحوث الزراعية - الدقى - الجيزة - مصر }
$$

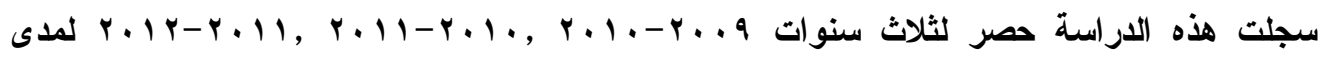
فقدان طوائف نحل العل في محافظة اسيوط ـ تم حصر الطوئف المفقودة والاسباب المحتملة للفقد باستخدام

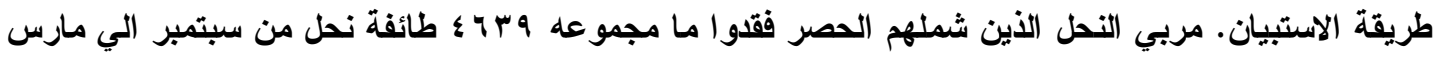

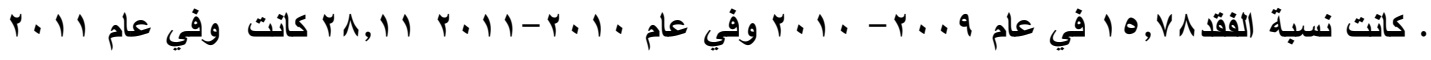

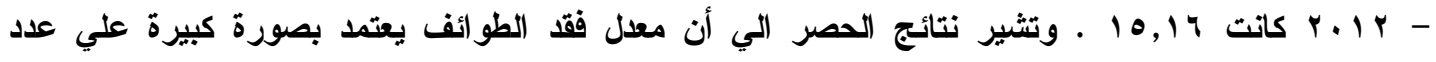

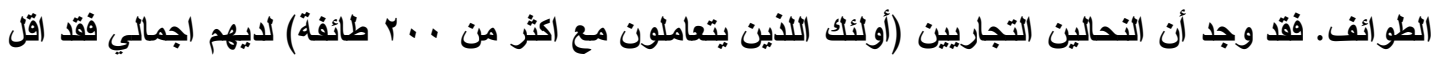

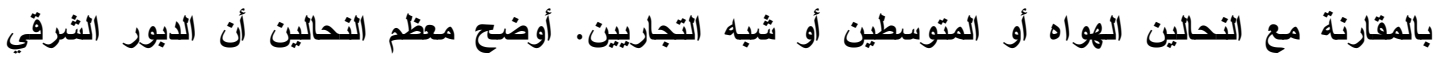

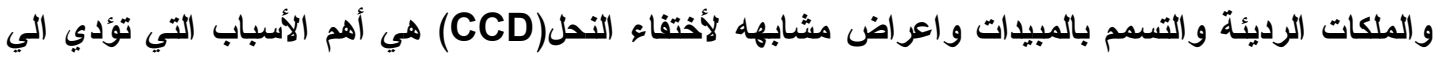
فقدان طوائفهم .في النهاية يجب ان يعمم مثل هذا الأستبيان في عموم مصر للوقوف علي حجم المشكلة ومحاولة لوانية فهمها و أيجاد الحلول لها. 